\title{
SUBSISTENCE FARMING IN RE-INDEPENDENT ESTONIA: EXPANDED PRIVATE PLOTS
}

\author{
Hans JÖRGENSEN
}

Department of Economic History, Umeå University, 90187 Umeå, Sweden; hans.jorgensen@ekhist.umu.se

This article presents an overview and summary of some issues discussed in my Doctoral dissertation: Continuity or Not? Family Farming and Agricultural Transformations in 20th Century Estonia, Umeå, 2004. A main departure - both for the dissertation and this article - is the long-term and comparative approach, which is seen as necessary for understanding the directions taken in the agricultural transformation in Estonia after 1991. The analysis of the development since restitution and de-collectivisation were introduced is based on the impact of long-term institutional and structural changes. These changes are here seen as outcomes of three profound economic, political and legal shifts since the first independence in 1918, which together have had an impact on Estonia's 20th century development and not least the agricultural transformation process since 1991.

The neo-institutional approach applied suits the analysis of the agricultural transformation processes and specifically changes appearing in terms of property rights. From this we can see that in spite of the absence of formal property rights in the Soviet Union, there was space for manoeuvring within the planned economic system by use rights, which implies institutional change. On the one hand, the private plots were not meant to be more than a transition solution, yet, they became institutionalised and prepared farmers for a shift towards private farming at the end of the 1980s. On the other hand, the private plots rested on a symbiotic relationship with the planned economic system. Thus, when market economic relations were to decide the future, the smallest farms of less than 10 ha had to turn toward pure subsistence production. It was after 2001 that a change was within reach due to the forthcoming membership in the European Union, which gave a better market outlook.

\section{INTRODUCTION}

Family-farm based production maintained a significant role in Estonia throughout the 20th century in spite of the fact that Soviet annexation and forced collectivisation led to the termination of private property in the 1940s. The process of de-collectivisation, which was carried through by means of restitution since 1991, also supported this idea. Restitution was based on the property relations of 1939, when 140000 family holdings possessed on average around 24 ha of land each. Prior to World War II around one-third of these farm units had less than 10 ha 
of land. ${ }^{1}$ In the post-1991 development many small-scale farms were thereby reconstructed. However, in the first post-Soviet years more than 90 per cent of the total farmland was also rented out on short-term basis. Furthermore, restitution itself was lined with legal impediments, not least numerous compensation issues, since much land could not be restored within its former interwar boundaries. ${ }^{2}$

Restitution aimed at a repossession of previously expropriated property and thus the process was in line with the political ambitions of erasing Soviet legacies and establishing historical justice in re-independent Estonia. ${ }^{3}$ However, restitution also tended to be an isolated legal issue, associated with values that were different from those of the 'extreme' liberal economic principles ruling most other areas of the post-Soviet transformation policies. While political compliance was shown to the uniform policies supplied by international advisors from the IMF, the World Bank and the EU, no coherent agricultural policy was formulated until the end of the 1990s.

The extremely liberal trade policy applied in Estonia since 1991 opened the country to an inflow of highly subsidised imports of foodstuffs from EU surplus production. ${ }^{4}$ This was done in a time when Estonia's Eastern markets almost vanished and the import regulations applied by the EU hindered a corresponding Estonian food export. During the first ten years of independence most re-created farms were thereby reduced into pure subsistence units. Estonia's post-Soviet agricultural transformation is a glaring contrast to the otherwise highly emphasised principles of economic efficiency and market orientation in the contemporary political discussions. However, a relevant question would be whether there were any other alternatives available to restitution in 1991. In response to this, a historical perspective can offer the experiences of previous - although not identical - transformations during periods of profound and quick shifts. Due to the role of legacies, patterns of both continuity and discontinuity can therefore be found, which help to structure the analysis of a long-term and comparative study of this kind.

This paper discusses some of the major findings in my Doctoral dissertation, which was based on four articles, and included an introductory chapter. Three out of the four articles focused on the interwar agricultural transformation in Estonia. The first compared the radical interwar land reform in Estonia and the contemporaneous reforms in Finland and Bulgaria. The second focused on the growth and development

1 Jörgensen, H. Continuity or Not? Family Farming and Agricultural Transformation in 20th Century Estonia. Dissertation, Department of Economic History, Umeå University, 2004.

2 Review of Agricultural Policies. Estonia. OECD, Paris, 1996, 18.

3 Kuddo, A. Aspects of the restitution of property and land in Estonia. - In: After Socialism: Land Reform and Social Change in Eastern Europe. Ed. R. Abrahams. Berghan Books, 1996, 159.

4 In contrast to Latvia and Lithuania or Poland, Estonia did not use any protective measures between 1991 and 2000. Free imports of foodstuffs gave a direct impact from the changes in world market prices on milk, meat, vegetables and grain. The custom duties imposed in 2000 only had a marginal effect since these concerned countries that were outside the EU and had not signed a free-trade agreement with Estonia. Ministry of Agriculture. Estonian Agriculture - Rural Economy and Food Industry. Tallinn, 2002, 12. 
of agricultural co-operative associations ${ }^{5}$ in Estonia in comparison to the Nordic Countries, Latvia, Lithuania and Bulgaria from the second half of the 19th century up to Soviet occupation in 1940. In the third article Swedish views on Estonia's butter export performance $1918-39^{6}$ were scrutinised. Finally, the fourth article explored the role of private plots in the Estonian Soviet republic and the development of small-scale subsistence farms after 1991.

Based on these four papers the synthesising ambitions of the introductory chapter were to explain how perceptions of markets and the role of agricultural production, changes in the agrarian property relations and organisation of agricultural production and co-operation contributed to specific patterns that can be understood as continuity of family farming. In short, the thesis thus pinpointed the long-term influences and legacies from previous institutional and structural changes on the transformation process in Estonia after 1991. If the four papers of the thesis were compressed into one major - and lengthy - conclusive sentence this would be:

Despite the fundamentally different ideological and economic-political doctrines that have directed the agricultural transformations in 20th century Estonia, perceptions of agricultural land in symbolic terms, rural lifestyle and small-scale agriculture as the ideal model for production have been preserved even though both producers' co-operative associations and export markets were impossible to restore after the societal changes brought forward by the large-scale and centralised ambitions of the Soviet planned economy. ${ }^{7}$

Thus it is possible to say that in the light of regained Estonian independence, the symbolic role of land and land ownership seems to have been more important than purely from economic efficiency aspects. The aim here is therefore to explore the continuity from the interwar family farming system through the Soviet private plots and the reconstruction of numerous subsistence farms in Estonia after 1991. Linked to this discussion the ambition is further to explain how the enlargement process of the EU gave incentives for changes that interrupted this continuity around 2001/2002.

\section{AGRICULTURAL TRANSFORMATION AND RESEARCH}

Beside the changes in agrarian property relations, the radical and decisive shifts in 20th century Estonia have affected markets, trade and economic integration. Estonia has been quickly thrown between forced adaptation to different economicpolitical systems and legal environments. From the perspective of the small state's

5 Jörgensen, H. Lantbrukskooperationen i Estland - Framväxt och problembild i Baltikum med utblickar till Norden och Östeuropa under mellankrigstiden och idag. - In: Jordbrukarnas kooperativa föreningar och intresseorganisationer i ett historiskt perspektiv. Ed. R. Rydén. Skogs och lantbrukshistoriska meddelanden nr 32, Kungliga Skogs och Lantbruksakademien, 2004.

6 Jörgensen, H. Competition and market: Swedish views on Estonia's agricultural development and butter-export 1918-39. - Acta Historica Tallinnensia, 1999, 3, 109-129.

7 Jörgensen, H. Continuity or Not?, 3. 
dependence on trade and reliance on few markets, the upheavals in the early 1920 s, the post-war development, and not least the fall of the Soviet Union, this has given long-term implications.

Looking back on the exposure to several radical shifts from 1918 on, the distinctive traits of each transformation have affected later developments. The agricultural transformations ${ }^{8}$ carried out in the post-Soviet states and East-Central Europe since 1989/91 are examples of these palpable changes. The structural changes in property and ownership relations as well as in agricultural production in general gave two visible effects in Estonia. Between 1992 and 2002 there was a general decrease in agricultural production and agricultural exports. The share of agriculture in GDP fell more than three times and so did agricultural exports. ${ }^{9}$

Decollectivisation, which comprises the conversion or dissolution of Sovietstyle kolkhozes and sovkhozes and the transfer of land to individually operated farms through restitution, implied a repossession of the land and property that were nationalised and expropriated in conjunction with Soviet annexation in 1940. In East-Central Europe this re-privatisation of land and farmsteads into the hands of legitimate owners has been denoted "the myth of reversible history", referring to the assumption that "forty-five years of communism were a kind of black hole" that could be filled with something different. ${ }^{10}$

During the first years of the 1990s the scholarly debate paid little attention to the complexity associated with agricultural transformation issues. A majority of the early, so-called transition studies concentrated on privatisation policies and strategies, macro-economic stabilisation and the impact of alterations of the legal and political environment in the former planned economies. ${ }^{11}$ In his recommendations for a radical shift, one of the most well known advocates of the big-bang approach Åslund (1992) warned that an overly hasty privatisation of Soviet style agriculture would create rural unemployment and pressures on urban areas. He even feared that subsistence farming would replace the large-scale units since export of foodstuffs from the East would meet the highly protective West-European markets. ${ }^{12}$

8 In this paper, I will consequently use the notion transformation instead of transition since the former term is both more suitable for a long-term historical approach and also takes into consideration the uncertain character of profound societal changes such as the one imbedded in post-Soviet development. With regard to the agricultural transformation, based on extensive alterations in the agrarian property relations, production structures, as well as in the associated processing facilities and services, this also suits better a historical approach.

9 Ministry of Agriculture. Estonian Agriculture, 2002, 9.

10 Fowkes, B. The post-Communist Era - Change and Continuity in Eastern Europe. MacMillan Press Ltd, 1999, 29.

11 See e.g. Nørgaard, O., Hindsgaul, D., Johannsen, R. \& Willumsen, H. The Baltic States after Independence. Edward Elgar, 1996 or Haavisto, T. (ed.). The Transition to a Market Economy. Transformation and Reform in the Baltic States. Edward Elgar, 1997.

12 Even though this was not more than marginal reasoning, his views were quite exceptional for the first generation of transition literature. Åslund, A. Post-Communist Economic Revolutions How Big a Bang? Washington, DC, Center for Strategic and International Studies, 1992, 78. 
An early study by Brooks et al. (1991), however, showed the importance of agricultural production in former planned economies, roughly employing 25 per cent of the workforce and contributing 20 per cent of GDP in 1989. Due to the absence of property rights, distorted retail food markets, the poor incentives to work and high costs of production, they concluded that "agricultural transition is an essential part of the stabilization and adjustment in East and Central Europe because agricultural sectors are large and food is important"13.

In addition, regional surveys such as the often-quoted van Arkadie \& Karlsson ${ }^{14}$ not only pinpointed the economic implications of political independence in the three Baltic States but also elucidated a set of general and specific problems associated with the transformation process, e.g. to withhold functional relations in trade with the former Soviet Union, both for the access to agricultural inputs as well as export markets while simultaneously carrying through property reforms and decollectivisation.

In the last ten years, research on agricultural transformation has been profound. ${ }^{15}$ The specific OECD report on Estonian agriculture (1996) was a good example of how the problems of post-Soviet agricultural production were merged with longterm institutional perspectives. ${ }^{16}$ The World Bank report by Csaki \& Nash ${ }^{17}$ further pinpointed the problems of agricultural transformation in comparison between East-Central Europe and the former Soviet Union. Large differences were shown in terms of the progress of reforms, but a general conclusion was that the process was said to be "considerably more complicated and complex than originally expected and results of the reform process to date have only achieved a part of those original expectations".

In a study based on extensive fieldwork, Wegren analysed the Russian agrarian reforms after the collapse and the difficulties for the Russian kolkhoz members after 1992 to become independent farmers since the bureaucratic and hierarchic

13 Brooks, K. et al. Agriculture and the transition to the market. - Journal of Economic Perspectives, 1991, 4, 5, 149-152, quotation 160-161.

14 Van Arkadie, B. \& Karlsson, M. Economic Survey of the Baltic States - The Reform Process in Estonia, Latvia and Lithuania. London, Pinter Publishers, 1992, 3-4, 293-294.

15 See for instance Swinnen, J. F. M. et al. Agricultural Privatisation, Land Reform and Farm Restructuring in Central and Eastern Europe. Ashgate, 1997; Swinnen, J. F. M. Political Economy of Agrarian Reform in Central and Eastern Europe. Ashgate, 1997; Hartell, J. G. \& Swinnen, J. F. M. Agriculture and East-West European Integration. Ashgate, 2000, which explicitly investigate the impacts of East European agriculture in association with the enlargement of the EU. Other studies of the post-Soviet property changes are e.g. Wegren, S. K. Agriculture and the State in Soviet and Post-Soviet Russia. University of Pittsburg Press, 1998. See also Lerman, Z. C. \& Feder, G. Land Policy and Changing Farm Structures in Central Eastern Europe and Former Soviet Union. 2001, e-version: http://www.agri.huji.ac.il/ lermanzv/book.html

16 See e.g. part I of Review of Agricultural Policies, 33-60, which draws attention to how the development after the 1940s has affected Estonian agriculture.

17 Csaki, C. \& Nash, J. The Agrarian Economies of Central and Eastern Europe and the Commonwealth of Independent States - Situation and Perspectives. Washington, World Bank, 1998, x. 
structures were able to obstruct the plans of potential independent farmers. ${ }^{18}$ Several failures in rural Russia in the 1990s were due to state mismanagement, such as the poorly designed reforms. The makers of the reforms and the advisors from the West had further totally misunderstood the relationships that they were supposed to change. The reform legislation deliberately created a "limited income potential" since the emphasis on egalitarianism was essential. As Wegren shows, the agrarian reforms and legislation were supposed to solve a number of economic shortcomings, but when the reforms were implemented, they turned into political issues. ${ }^{19}$ Wegren continues: "Emphasis on egalitarianism and collectivism in the rural sector predated the Soviet period. Thus in a broader context reform behaviour must be understood as resulting from continuities in political culture on the part of those who govern and those who are governed."20

Since the large-scale kolkhozes and sovkhozes were integrated units and functioned more as local municipalities, it is reasonable to assume that rural citizens in the peripheral parts of Estonia experienced profound disadvantages when this kind of infrastructure and associated services broke down as outcomes of decollectivisation. $^{21}$

\section{Institutional aspects and property relations}

The neo-institutional approach is not based on heterogeneous theory construction. It is, however, a useful tool for understanding the transformation context. According to North "institutions are the rules of the game" or the "humanly devised constraints" $"$. Institutions form the incentive structure of societies and economies and reduce uncertainty by providing structure to daily life. They consist of formal constraints such as laws, constitutions, and codified rules and informal constraints, such as customs, norms, values and sanctions. ${ }^{23}$ Here the analytical focus rests on explanations of why changes of the "rules of the game" appear or do not appear. This enhances how adjustments to specific rules - or the social institutions - can be understood in a long-term perspective. The motives and outcomes of different transformation processes depend on the characteristics of formal and informal restrictions. In other words, any institutional environment is formed by specific restrictions, which are crucial for the historical analysis. In this regard the main focus is on the understanding of changes in the property relations in Estonia from a 20 th century perspective.

18 Although the comparison is not made, this is reminiscent of the peasants' problems of leaving the Russian 'mir' before the Stolypin reforms 1906-11. Wegren, S. K. Agriculture and the State in Soviet and Post-Soviet Russia, 150.

Ibid., 228-231.

Ibid., 229.

21 Unwin, T. Agricultural restructuring and integrated rural development in Estonia. - Journal of Rural Studies, 1997, 13, 1, 99.

22 North, D. C. Institutions, Institutional Change and Economic Performance. CUP, 1991, 3.

23

North, D. C. Institutions, 3-5. 
Although institutions reduce uncertainty and give structure to the interplay of organisations, less appropriate or effective institutions can exist. Throughout history rapid formal institutional changes have been made, but these have met a slow process of adaptation in the informal constraints, which are sluggish by nature. Quick shifts therefore point to the problem of legitimacy: will people e.g. behave in accordance to new laws or restrictions? In the case of the demise of communism in 1989 and 1991, most of the formal institutional framework was destructed while many of the informal constraints survived. ${ }^{24}$

The role of institutions within a specific national context can, according to Whitley, be divided into two different categories: social background institutions and proximate institutions. While the former permeate all economic activity, through the reproduction of specific cultural patterns they also indirectly affect the latter. The proximate institutions are more related to the functioning of the market and are shaped by policies, aiming at delivering dynamism to the gap left by, e.g., cultural heritage. ${ }^{25}$ Still, it is reasonable to assume interdependence between these two institutions since they interact and contribute to both stability and change within a specific political system.

Agricultural transformation creates far-reaching effects on the agrarian property relations and the associated production activities. When changes concerning the ownership of agricultural land are analysed, the notion of property rights is therefore essential. Property rights function as an instrument of society. It is a fundamental institution, which includes consent from fellowmen as well as "convey the right to benefit or harm one-self or others" ${ }^{26}$ Property rights, however, do not presuppose a system based on private property. Rather they constitute a bundle of rights, stretching from access or use rights to ownership rights to a specific resource, but most importantly, they legitimise the relationship between the person/persons who dispose a resource and those affected by this use. Property rights are therefore dependent on the specific context in which they are exercised. This implies that both time and space determine the significance of the notion. ${ }^{27}$

As far as land is concerned, property rights thus range from restricted use rights, lease-holding agreements through to exclusive ownership rights, which are legally codified in laws, documents and customs. If property rights can be seen as an instrument of the society the interwar peasants' movements constituted a social force. In her vast study of the interwar land reforms in East-Central Europe, Warriner (1939) stated: "The post-war land reforms greatly strengthened the peasants everywhere, transforming large numbers of labourers into owners, even in

24 North, D. C. The Contribution of the New Institutional Economics to an Understanding of the Transition Problem. Wider Annual Lectures 1, UNU/WIDER, 1997, 16.

25 Whitley, R. European Business Systems. Sage, 1994, 19, 25-26.

26 Demsetz, H. Towards a Theory of Property Rights. - The American Economic Review, 1967, 57, 2, 347.

27 For these perspectives, see e.g. the introductory section in: Widgren, M. Äganderätten i lantbrukets historia. - Borås, 1995. 
Rumania, creating an independent peasantry." 28 In the previous parts of empires where these land reforms took place, ownership rights therefore contributed to major changes of the property relations.

In contrast to the slow property changes after the 1850 s, the Estonian land reform of 1919-1926 entailed a radical change in the ownership structure through the expropriation of not only Baltic-German estates but in fact all land. The redistribution that followed was from 1926 onwards crowned by full ownership rights. In this sense the pre-independent tenant peasants and landless took control of one of the most valuable resources Estonia possessed. Ownership rights also constituted the basis for both mortgage loans and land transfers. This further gave incentives for long-term improvements such as land amelioration and pipe draining. The division of land among peasants thus constituted the foundation for continuing institutional changes as co-operative growth and the build-up of relevant supportive structures. ${ }^{29}$

The 140000 Estonian family farms, averaging 24 ha per unit, provided the basis for the successful producers' co-operative associations in the 1920s and 1930s. State support for the co-operative organised export of butter and meat enhanced successful marketing in Western Europe until the worldwide economic depression and the authoritarian political development began. Co-operative growth and export orientation were, however, stimulated already in the late 1800s due to the increasing demand in the St. Petersburg area. The interwar co-operative growth did not have a corresponding demand to rely on. Trade with Soviet Russia was aggravated by the revolutionary development and, not least, the Soviet isolated planned economy. Instead, it was the joint forces of the government, the co-operative associations and the peasants themselves that formed the basis for the export orientation: "a supply-push strong enough to give them a foot-hold in the markets of Western Europe" 30 .

When Estonia was annexed by the USSR in 1940, private ownership of land was immediately abolished through nationalisation. Two forms of ownership relations were, however, applied: socialist ownership and personal ownership. A household could keep personal belongings such as the necessary tools and things needed for production on the private plots. All assets and productive resources were, on the other hand, state property. ${ }^{31}$

The absence of private property rights to land turned the property relations concerning the private plots into a specific semi-private environment. Operative management of land was handed over to the plotholder from the state, i.e. property could be used but with specific restrictions. There were thus no open rights for the plotholder. Land could not be sold, except for sanctioned transfers of user rights within the household. Still, the system allowed for exclusion, as long as

28 Warriner, D. Economics of Peasant Farming. London, 1939, 25.

Kõll, A.-M. Peasants on the world market. Agricultural experience of independent Estonia 1919-39. - Studia Baltica Stockholmiensia, 1994, 14, 63.

31 A Study of the Soviet Economy, Vol. 2. OECD, Paris, 1991, 241. 
cultivation was based on single management, since the plotholder was also in charge of the income derived from the plot. From a production perspective, a two-sided control system was applied based on external and internal control. The former depended on how the specific institutional environment restricted the plotholder and his relations with other actors. The latter referred to the plotholder's own investments in land, such as fences, fertiliser for improving the soil quality or other types of inputs. ${ }^{32}$

In the profound reorganisation of agricultural production taking place during the various transformations, the build-up of relevant institutions has been decisive for the performances of the different farm units. Any producer has needed to adapt to various institutional settings, both on a national as well as on an international level. But a major problem associated with restitution of land and assets after 1991 is the fact that many assets cannot be recreated in their former shape since they have simply vanished. This concerns both land and buildings. Different types of maintenance - or the lack of maintenance - also turn restitution into a kind of lottery or a process characterised by numerous compensation issues. ${ }^{33}$ Still, the post-Soviet agricultural transformation in Estonia must be understood in the context of the aspirations to restore the property relations that existed prior to Soviet annexation. This also necessitated the build-up of new relations in trade. From the horizon of institutional change transformation has thus meant a total upheaval in the economic, political and legal fields. Each quick shift has, in North's terminology, altered the rules of the game and brought forward changes among the associated organisations. ${ }^{34}$

Due to the legal implications from previous Soviet laws and reforms, the deteriorating post-Soviet markets and adjustments to the EU, as well as various compensation issues, restitution has been comparatively slow in comparison with neighbouring Latvia and Lithuania. But the steady growth of small farm units since 1991 also gives interesting perspectives on the transformation of private plots to subsistence holdings.

\section{ESTONIAN AGRICULTURE IN A LONG-TERM PERSPECTIVE}

Scrutinising the long-term agricultural development shows how intertwined e.g. the changes in the agrarian property relations and the structure of production have been with the general transformation process, both during the interwar period and in the post-Soviet years. After the national awakening in the late $1850 \mathrm{~s}$ perceptions of individual ownership to land, linked with the idea of "land to the cultivator", became a key issue. The symbolism surrounding agricultural land and

32 For a discussion on external and internal control, see Eggertsson, T. A note on the economics of institutions. - In: Empirical Studies in Institutional Change. Eds. T. Eggertsson \& J. L. Alston. Cambridge, 1996, 8-9.

33 Rabinowicz, E. EU:s jordbrukspolitik och bönderna i Öst. Stockholm, 1996, 26-27.

34 North, D. C. Institutions, 2. 
small family based production realised during the interwar independence explain the aversion shown towards large-scale Soviet style agriculture. ${ }^{35}$

Agricultural production in Estonia deviated from the general Soviet-Russian context due to different institutional legacies. While the interwar period in Soviet Russia was characterised by revolution, civil war, nationalisation, forced collectivisation and the introduction of a command economy, national independence in the Baltic States in 1918 led to profound economic and political changes in a different direction.

The forced collectivisation that took place in the Soviet Union in 1929-1934 can, as shown by Allen, be denoted "Preobrazhensky in action", here implying that collectivisation was a means for collecting taxes or creating a transfer of capital from peasants in order to pay for industrialisation. Thus, prices were cut for the producers and substantially raised with turnover taxes before the foodstuffs were sold to the consumers. In the late 1930s this exploitation of the collectivised peasantry thereby gave resources for Stalinist industrialisation and the burden was born by the peasants. ${ }^{36}$

Due to the resistance in the countryside and the immediate food shortages that followed with collectivisation, concessions to the peasants were needed. One of these was to give legal entitlement to the private plots and the kolkhoz market, which due to widespread famine became a necessary retreat from the ambitious full-scale socialisation. ${ }^{37}$ In the late 1930 s, new taxes, procurement quotas and administrative controls were introduced, officially as anti-capitalist campaigns against the kolkhoz peasants' use of enlarged plots and excessive numbers of livestock. ${ }^{38}$ It was also originally assumed among Soviet policy makers that there was no need for any production incentives for kolkhoz members as long as there were no alternative means for obtaining money incomes. However, a system of informal rewards and payments for plan fulfilments developed, which needed to be met by specific incentives for facilitating the objectives of rapid industrialisation, since a large proportion of the most successful and well-to-do peasants in the USSR were deported in the 1930s. ${ }^{39}$ The Communist Party of the Soviet Union was therefore constantly debating how large-scale farms could increase efficiency, which in fact had been a recurrent theme since the revolution.

35 Abrahams, R. \& Kahk, J. Barons and Farmers. Continuity and Transformation in Rural Estonia (1816-1994). Gothenburg, 1994, 31-32.

36 Allen, R. C. Farm to Factory. A Reinterpretation of the Soviet Industrial Revolution. Princeton University Press, 2003, 173-175.

37 Hedlund, S. Soviet Union. The anomaly of private-cum socialist agriculture. - Proceedings, American Agricultural Economics Association, 1988, 418.

38 Figures disclosed in the 1960s showed that the kolkhozniks as a whole did not even exceed the statutory limits in any regard. See Lewin, M. The Making of the Soviet System, Essays in the Social History of Interwar Russia. London, Methuen, 1985, 179.

39 Kahan, A. The collective farm system in Russia: some aspects of its contribution to Soviet economic development. - In: Agriculture in Economic Development. Eds. C. Eicher \& L. Witt. New York, 1964, 254-255. 


\section{The role of the state}

Soviet annexation in 1940 forced Estonia into a different system of trade and production. Through nationalisation of land, followed by forced collectivisation and full subjugation to the planned economic production, the conditions for agricultural production became totally different. ${ }^{40}$ State involvement was a precondition for the Soviet planned economy, and if a rapid increase in agricultural production was one of the most immediate concerns among governments in post-war Europe, the Soviet Union was on the same track. But while Western Europe's agricultural productivity development was rising due to relatively higher investments in mechanisation, and already returned to the pre-war levels around 1949/50, Soviet agricultural production did not increase as fast as industrial production. In European agriculture the trend was in fact faster productivity growth than in industry up to $1959 .^{41}$

In post-war Western Europe, various national regulations have been in force affecting the production and trade of foodstuffs, not least the Common Agricultural Policy (CAP) after 1957. Even though the Soviet Union and the CMEA sphere represented a different form of integration, based on co-ordination of economic planning and production, and a high degree of barter trade, features of planning have evidently been present in West European development as well. The main difference, besides the involuntary association of the CMEA, was the overall planning, which meant centralised and state-directed transfers of resources and inputs and the absence of a convertible currency. For the Soviet republics and CMEA states this created a specific dependence on the transfer of Soviet resources and raw materials, which were exchanged with manufactured goods on a bilateral basis.

The forced collectivisation in Estonia was performed very much on the same lines as in the Soviet Union in the early 1930s. An initial land reform in 1940 stipulated farm size limits of 30 ha, which were used for the transfer of land and assets to landless and poor people. ${ }^{42}$ The first kolkhozes were founded in conjunction with annexation and the birth of the Estonian Soviet Socialist Republic (ESSR) in $1941 .{ }^{43}$ Forced mergers of family farms thereby gave the same subjugation to the all-Union command economy. In July 1950, more than 98 per cent of all

40 Jörgensen, H. Continuity or Not?, 108-109.

Tracy, M. Government and Agriculture in Western Europe 1880-1988. Exeter, 1989, 217-218.

42 This was made by the communists in order to gain sympathy from the least well-off peasants "and to create a split between them and the countryside bourgeoisie; the kulaks, which were the losers in this reform". See Kõll, A.-M. Tender wolves. Identification and persecution of kulaks in Viljandimaa 1940-49. - In: The Sovietization of the Baltic States, 1940-56. Ed. O. Mertelsmann. Tartu, 2003, 131.

43 But after the interlude of German occupation 1941-44, which in fact did not alter Soviet policies, these were not revived. Soviet power from 1944 on was directed towards voluntary collectivisation, which however was too slow and from 1947 tax payments increased followed by kulak hunting and the great deportations in 1949. Taagepera, R. Soviet collectivisation of Estonian agriculture: the taxation phase. - Journal of Baltic Studies, X, 3, 1979, $263 \mathrm{ff}$. 
land was collectivised and 2313 kolkhozes and 127 sovkhozes were established. ${ }^{44}$ However, a few remote and isolated small private farms still possessed less than 1 per cent of the land in 1955. In addition, small plots belonging to city workers and employees constituted 6-7 per cent of the total arable land. ${ }^{45}$

Yanov's studies in the late 1960s showed how rigid production structures were maintained and scientific innovations and methods were rejected in large-scale farming. The whole system fostered mistrust, but even worse was the lack of incentives. Yanov answered the question whether the system worked by concluding: "depends on what one means by 'work'. If it refers to political control, then the kolkhoz system works very well; if it refers to food production, then the system does not work, for it was not designed to" ${ }^{46}$ The major problem was the superiority of politics over common sense, which implied centralised and uniform strategies, regardless of local and regional preconditions. One reaction to these instructions from the top came from the Estonian Minister of Agriculture (1953-1965), Edgar Tõnurist, who wrote a clarifying article in 1964 against the recommendations of using more mineral fertilisers for increasing yields to catch up with Sweden and Finland. He stated: "Our soil cultivation tools are partly responsible... No chemistry will help if the Agrotechnical ABC-book has been forgotten." ${ }^{, 47}$ In other words, the problem was a general lack of proper machinery for tillage.

Forced into the planned economic production system, Estonia nonetheless became the top agricultural producer of the Soviet Union from the early 1960s. However, the republic became totally dependent on inputs of fertilisers and protein feeds from other republics as well as their demand. In the stagnation period, from the late 1960s, increased agricultural investment helped to maintain this position. From the late 1970s and throughout the 1980s the rural areas attracted more people both because of the need of labour and the better conditions for living. The Estonian kolkhoz leaders were able to use federal investment not only for agricultural purposes but also for the construction of - in a Soviet perspective - attractive housing. However, throughout the 1980s, the access to larger private plots also encouraged households to settle down in rural areas. ${ }^{48}$

Perestroika and glasnost after 1986 had important institutional and structural impacts on the post-socialist agricultural transformation process in Estonia. The bases for these changes were to be found on the one hand in the deficient performance of Soviet agriculture and, on the other hand, in the experiences from production on private plots and reorganisation of farm work towards family based units. The brigade-contract system was first introduced on a very limited scale during the reign of Yurij Andropov in 1982, but was closely observed by Mikhail

44 Eesti NSV rahvamajandus 1974. aastal. Statistika aastaraamat. Tallinn, 1976, 125.

45 Järvesoo, E. Progress despite collectivisation: agriculture in Estonia. - In: Problems of Mininations. Baltic Perspectives. Eds. R. Taagepera et al. San José, 1973, 140-141.

Yanov, A. The Drama of the Soviet 1960s - A Lost Reform. Berkely, 1984, 22.

Purre, A. Soviet Farming Failure Hits Estonia. Stockholm, 1964, 19-20.

Jörgensen, H. Continuity or Not?, 162-168. 
Gorbachev (the chief of agriculture in the Central Committee), who developed these ideas further. ${ }^{49}$ The agricultural reforms, which grew out of these ideas, started in the Baltic Soviet republics and in 1987-1988 the first reform farms were created. Up to independence roughly 2000 reform farms were established. Private property was, however, inconsistent with Soviet law. After independence in 1991 decollectivisation was therefore initiated.

In the years 1987-1991 several patterns can be found that may be considered important from the aspect of continuity and discontinuity. First, the changes began in a time of unrest, characterised by a search for alternatives. Secondly, reforms had been a constant theme in Soviet politics, but most of them had failed, as they had not always been approved by the most influential within the Communist Party. Finally, because of the mix-up of different legacies and perceptions, in the aftermath of the eased conditions after Brezhnev's death and introduction of perestroika, the internal Soviet development was marked by contradictions. All this fostered specific behaviour, which presumably influenced the choices made after the regained Estonian independence.

Due to the inbuilt problems of large-scale Soviet farming, and not least the distorted relative prices, the changes that appeared in conjunction with perestroika and glasnost in the late 1980s helped to spread the myth of the profitability of small-scale production. ${ }^{50}$ But as it turned out, it was impossible for the small-scale semi-private farms or private plots to continue to operate without the surrounding planned economy as a major supplier and market. After independence the whole agricultural infrastructure system broke down.

\section{Towards de-collectivisation}

Successful de-collectivisation needs to be combined with measures that facilitate production. If the aspired or intended farm structure is one of small-scale family farms, this requires backup from an institutional infrastructure, which can supply necessary means for production, e.g. in the form of producers' co-operative associations that can enable the small-scale producers to make use of the advantages of scale. However, to restore what was built up in the 1920s has proved far more complicated than initially anticipated. A major problem is, e.g. that many kolkhozes and sovkhozes were integrated production units, not suitable for division into freestanding shares. To divide assets belonging to large-scale farm units is hard. When this is performed in association with the reconstruction of obsolete property structures - as in the case of Estonia - it shows that the post-Soviet agricultural

49 Goldman, M. Lost Opportunity. What has Made Economic Reform in Russia so Difficult. New York, London, 1996, 66.

50 Tamm, M. Appendix: Agricultural reform in Estonia. - In: Decollectivisation, Destruction and Disillusionment - A Community Study in Southern Estonia. Eds. I. Alanen et al. Ashgate, 2001, 411. 
transformation has been guided by political and ideological motives rather than economic efficiency criteria. ${ }^{51}$

Many rural people had great expectations in the late 1980s, when the first reforms allowed private farmers to begin on kolkhoz and sovkhoz land. However, these farmers were often not the original owners, which in the post-1991 development has led to numerous compensation disputes. ${ }^{52}$ Furthermore, the restitution process starting from 1991 was not co-ordinated with decollectivisation. Restitution was a nationally directed legal process, while decollectivisation was to be conducted on a local level. Thereby a situation appeared after 1991, where the big tractors, harvesters and combines ended up as the possessions of small-scale farmers for whom the cost of fuel and spare parts exceeded the net incomes from their land. ${ }^{53}$ Under conditions characterised by quick shifts, the division of agricultural real capital such as land, machinery, cattle and buildings is thus not easily solved.

In 1989, 330 kolkhozes and sovkhozes, averaging more than 3700 ha per unit, formed the basis for Estonia's agricultural production, which from a marketing perspective relied on the Soviet demand. Independence in 1991 followed by the currency reform in 1992, however, quickly altered these relations.$^{54}$ Estonia also met a different trade environment than the one it was forced to leave in 1940. In the 1930s protectionist policies were applied all over Europe due to the depression, yet it was possible to access other markets by concluding bilateral agreements. After the dissolution of the Soviet bloc there was no corresponding route of access to the European Union's markets for non-members. Thus, bilateral agreements had to be concluded, foremost with East-Central European countries or with other former Soviet republics, which had achieved independence but were producers of similar products.

Estonia's choice of strategy in the 1990s has deviated from that of most other former planned economies in the sense that a very liberal trade regime has been applied. On the one hand this gave substantial foreign direct investment in industrial production, but on the other hand, nothing to agricultural production. Most postcommunist countries have in fact applied a certain amount of protective measures due to the relative size of - and dependence on - agricultural production. In addition, if the transformation of the agricultural production system had been guided by principles associated with efficient production units, the recreation of obsolete property relations through restitution would have needed support from policies that facilitated both land transfers and the build-up of refinement and marketing. However, in Estonia the trend was for many years the opposite. These issues will be further discussed in the concluding analysis.

51 Rabinowicz, E. EU:s jordbrukspolitik, 20-23, 144-145.

52 Kuddo, A. Aspects of the restitution of property and land in Estonia. - In: After Socialism. Land Reform and Social Change in Eastern Europe. Ed. R. Abrahams. Providence, Oxford, 1996, 162.

53 Alanen, I. The dissolution of the Kanepi Kolkhoz. - In: Decollectivization, Destruction and Disillusionment - A Community Study in Southern Estonia. Eds. I. Alanen et al. Ashgate, 2001, 224-229.

54 Review of Agricultural Policies, 62. 
Table 1 and Figure 1 are based on the same data and support each other. Table 1 gives the absolute figures of the operating and non-operation farm holdings and Fig. 1 shows how the relative distribution of land has changed between 1991 and 2001. In Figure 1, however, farms possessing more than 100 ha cannot be distinguished. They only constituted between 0.6 and 0.9 per cent during the 10 -year period. The number of farms possessing less than 10 ha of land increased throughout the period, except for a slight reduction in relation to other farm sizes in the years 1996 and 1997. Most remarkable, however, is the almost fourfold increase in the number of farms possessing less than 10 ha, i.e. subsistence holdings, after 1996.

Table 1. Number of holdings (operating and non-operating) in Estonia 1991-2001

\begin{tabular}{c|r|r|r|r|r|r|r|r|r|r|r}
\hline $\begin{array}{c}\text { Farm-size, } \\
\text { ha }\end{array}$ & 1991 & 1992 & 1993 & 1994 & 1995 & 1996 & 1997 & 1998 & 1999 & 2000 & 2001 \\
\hline-5 & 164 & 576 & 659 & 818 & 1634 & 3490 & 2901 & 4941 & 6269 & 8798 & 10790 \\
$5.1-10.0$ & 244 & 894 & 1040 & 1298 & 1827 & 2898 & 3644 & 5865 & 7147 & 8980 & 11078 \\
$10.1-20.0$ & 581 & 1881 & 2269 & 2823 & 3750 & 5272 & 6364 & 9545 & 11446 & 13744 & 16161 \\
$20.1-30.0$ & 539 & 1499 & 1804 & 2191 & 2721 & 3574 & 4299 & 6216 & 7247 & 8474 & 9707 \\
$30.1-50.0$ & 581 & 1511 & 1811 & 2090 & 2488 & 3175 & 3800 & 5519 & 6380 & 7573 & 8891 \\
$50.1-100.0$ & 213 & 631 & 784 & 879 & 1027 & 1273 & 1574 & 2347 & 2677 & 3152 & 3742 \\
$100.1-$ & 17 & 17 & 45 & 54 & 66 & 85 & 140 & 238 & 280 & 360 & 526 \\
Total & 2339 & 7009 & 8412 & 10153 & 13513 & 19767 & 22722 & 34671 & 41446 & 51081 & 60895
\end{tabular}

Source: Statistical Office of Estonia.

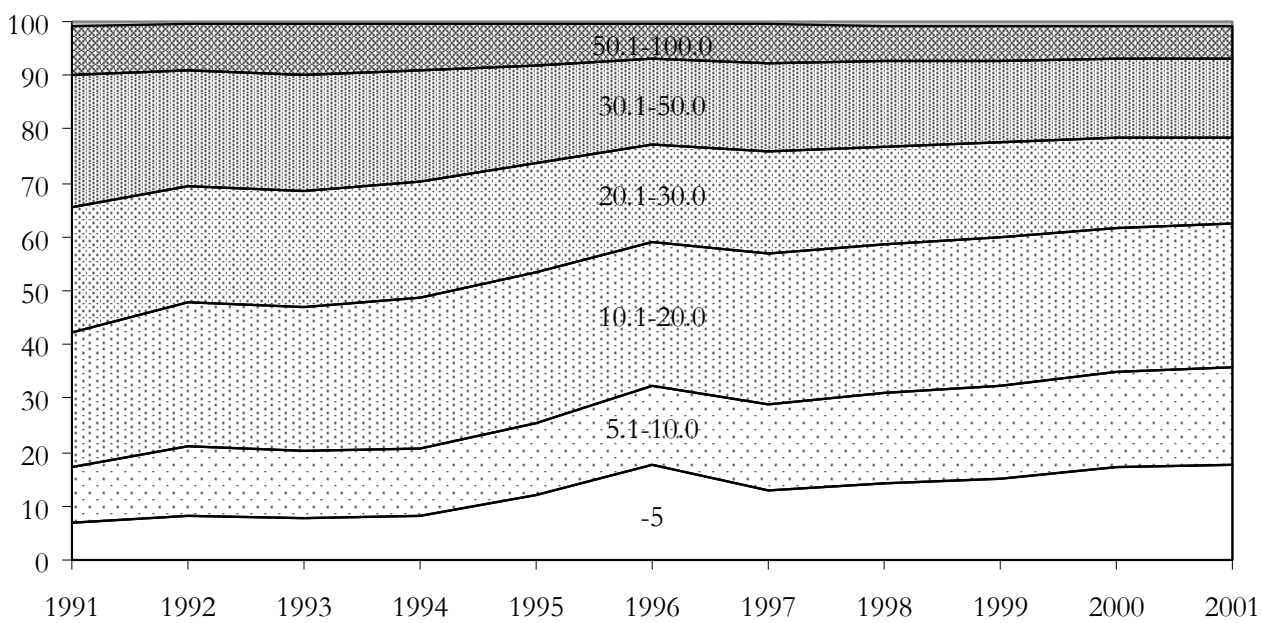

Fig. 1. Relative distribution of holdings (operating and non-operating) in Estonia between 1991 and 2001. Source: Statistical Office of Estonia. 
There is also a quantitative factor to consider. During the first years after 1991, restitution was a slow process and the market situation did not encourage land transfers. After 1996, however, the government increased the efforts on concluding more restitution and compensation cases. For some time these measures led to an increase in the numbers of farms possessing more than 5 ha, but also since the relatively better market outlook spurred land transfers. People in possession of smaller units thus sold their land on to larger farms, foremost around 1996 to 1997. This was at the time when there were hopes for a recovery of the Russian market. However, between 1997 and 2001 the smallest farms - as a group - increased again from 2901 to 10790 . Farms between 5 and 10 ha increased from 3644 to 11078 in the same period. This was due to both new concluded restitution cases as well as less sales because of the gloomy market outlook after the Russian financial crisis.

Prior to Soviet occupation in 1939, 45000 farms had below 10 ha per unit. This constituted around a third of all farm units for which the average size was 24 ha. ${ }^{55}$ Ten years after the regained independence restitution had re-created more than 20000 operating farms that possessed below 10 ha of land.

In July 2001, farms above 100 ha possessed on average 414.3 ha of land, which constituted 1.5 per cent of all holdings and 48.2 per cent of all land. Almost 80 per cent of the farms cultivated less than 10 ha of land. Within this group 54879 holdings had on average 2.8 ha, which in terms of land constituted 17.5 per cent of the total. ${ }^{56}$

In recent years important changes seem to have occurred. Between 2001 and 2003 the number of operating subsistence holdings fell from 41102 to 25935 while the average size of holdings below 10 ha increased from 2.8 to 3.7 ha. The same development took place among farms with less than 50 ha, while those cultivating more than 50 ha increased both in terms of numbers and hectares. ${ }^{57}$ Using the European standard for calculating profitability, farms below 2 ESU (European Size Units) decreased from 46591 holdings in 2001 to 30385 in 2003. During the same period the size of an average Estonian holding increased from 15.5 to 21.6 ha and land under tenure was reduced by 10 per cent. ${ }^{58}$

Supports for this trend can also be found in the development of dairy production. As Table 2 shows, the number of dairy cows fell by more than half between 1992 and 2002 accompanied by a clear reduction in the total volume of milk production until 1996. A slight upward trend, however, followed for some years. But after 1998, except for the temporary increase in 2001 when import tariffs on milk were introduced and probably rescued some producers, total milk production reached the lowest level ever in 2002. Interesting here is the qualitative change expressed

\footnotetext{
Konjunktuur, Nos. 57-58 (1939), 376.

Agricultural Census 2001, ESA (Statistical Office of Estonia), 31.

The Structure of Agricultural Holdings 2003. 2004, 8.

58 One European Size Unit (ESU) is equal to the value of the SGM (Standard Gross Margin) of 1.200 euros (18.768 EEK). SGM is the difference of the holding's output and the value of specific costs, calculated on the basis of crop area, number of livestock and SGM coefficients. See The Structure of Agricultural Holdings 2003, 5-7, 57.
} 
Table 2. Dairy production in Estonia 1992-2002

\begin{tabular}{|c|c|c|c|c|c|c|c|c|c|c|c|}
\hline Year & 1992 & 1993 & 1994 & 1995 & 1996 & 1997 & 1998 & 1999 & 2000 & 2001 & 2002 \\
\hline $\begin{array}{l}\text { No. of dairy cows } \\
\text { (1000) }\end{array}$ & 264 & 253 & 226 & 211 & 185 & 172 & 159 & 138 & 131 & 129 & 113 \\
\hline $\begin{array}{l}- \text { on enterprises } \\
(1000)^{\mathrm{a}}\end{array}$ & 213 & 189 & 143 & 133 & 113 & 102 & 98 & n.a. & n.a. & n.a. & n.a. \\
\hline $\begin{array}{c}\text { - on private farms } \\
(1000)^{\mathrm{b}}\end{array}$ & 8 & 15 & 22 & 23 & 24 & 25 & 31 & n.a. & n.a. & n.a. & n.a. \\
\hline $\begin{array}{l}- \text { on household plots } \\
\quad(1000)^{\mathrm{c}}\end{array}$ & 43 & 50 & 61 & 55 & 49 & 44 & 39 & n.a. & n.a. & n.a. & n.a. \\
\hline $\begin{array}{l}\text { Milk production } \\
\text { (1000 tonnes) }\end{array}$ & 919 & 807 & 772 & 706 & 674 & 717 & 730 & 626 & 630 & 684 & 611 \\
\hline $\begin{array}{l}\text { Milk production per } \\
\text { cow (tonnes) }\end{array}$ & 3.4 & 3.2 & 2.4 & 3.3 & 3.6 & 4.2 & 4.6 & 4.8 & 4.8 & 5.3 & 5.4 \\
\hline $\begin{array}{l}\text { Dairy deliveries } \\
\text { (1000 tonnes })\end{array}$ & 542 & n.a. & n.a. & n.a. & n.a. & n.a. & 532 & 404 & 409 & 430 & 495 \\
\hline $\begin{array}{l}\text { Dairy deliveries } \\
\text { (in per cent) }\end{array}$ & 59 & n.a. & n.a. & n.a. & 73 & n.a. & 73 & 64 & 65 & 63 & 81 \\
\hline
\end{tabular}

a Enterprise - a legal person whose main activity according to the Estonian Enterprise Register is agriculture. For the period 1992-1995 Enterprises include transforming or still working kolkhozes and sovkhozes.

b Private farm - holding with more than 1 ha of agricultural or forest land.

c Household plot - a family living in the countryside or in town who has an official document for land use or has livestock.

n.a. - not available.

Sources: Ministry of Agriculture of Estonia, European Commission (Eurostat), FAO-stat.

by the relative increase of milk delivered to dairies between 2001 and 2002. This can be further understood when the information on the simultaneous growth of larger holdings is added. It is also obvious that the production per cow has increased since 1994, which in fact was the worst year for Estonian farming after independence.

Owing to the fact that many Estonian subsistence holders have secured the access to fresh milk and meat by keeping a few cows and piglets, as was the case with the private plots during the Soviet period, changes within this group are important for the long-term analysis. Before 1998, the export of foodstuffs to Russia had in fact recovered for some years even though Russia had imposed a specific tariff on Estonian goods in 1994. ${ }^{59}$

In 1997 entrepreneurs saw excellent prospects for reclaiming the former markets, which was in fact an initial hope in the early 1920s as well. The general decrease in demand, declining imports of inputs and the Russian financial crisis, however,

59 Review of Agricultural Policies, 53. 
brought down the share of agricultural products in total Estonian export from 17.5 to 5.8 per cent between 1992 and 2000. A reasonable interpretation of this development since 1992 is that the adjustments to EU phytosanitary regulations, lower prices and the exposure to international competition hit first small producers, i.e. subsistence holders, who deliver a small share of milk to dairies or sell on to neighbours. New rules in force after 2001 have, however, altered this pattern. Most small-scale producers cannot afford the costs associated with the European Union's phytosanitary regulations for refinement, livestock breeding and buying-in-policies of milk and slaughter. ${ }^{60}$ This is also confirmed by taking a tour in the Estonian countryside. Several of my informers admitted that most of their neighbours, who used to keep up to 3-4 cows, have stopped dairy farming in the last two years, due both to the new regulations for deliveries, as well as the high costs associated with selling on local markets. In addition, the shrinking margins between production costs and price paid per unit of milk or meat have enhanced this development. But for the households that previously consumed all milk or meat by themselves the new regulations brought an end. The high veterinary costs and the investments needed for barn reconstruction, e.g. for milk production, do not allow for any exceptions and thus most rural people have traded the plot for the supermarket, at least for the access to milk and meat.

What links the post-Soviet subsistence holdings and the former private plot is the persistent subsistence character of cultivation to which the holder has been bound, both by tradition and necessity. Most subsistence holders belong to a group of rural people who lack proper education, sufficient incomes from work or elderly people with low pensions. They have used their small and poorly equipped farms as a means to secure the access to basic foodstuffs such as potatoes and milk during times of hardships. Yet in spite of restitution and the re-introduction of formal property rights, which are supposed to enhance land transfers and increase efficiency in production, the cheap imports, accompanied by disputes over drawnout compensations, widespread land transfers did not make any real breakthroughs before 2001. It remains to be seen whether the new trend will keep on and lead to further mergers of small subsistence holdings and perhaps thereby bring the remnants of "subsistence holdings" or "private plots" back into the functions of a garden for flowers and early vegetables as in most parts of the Western World.

\section{CONCLUSIONS}

It is possible to find a certain amount of nostalgia in the conceptions of the pre-war independent farming system of the $1980 \mathrm{~s}$, due to the distorted relations that appeared in prices and costs, which led to a belief in the viability or competitiveness of small-scale farms. In these relations, a main problem is to be found. The private plots preserved the interwar farming ideals but at the same time, as isolated units outside the reach of the surrounding world, they were fully

${ }^{60}$ Ministry of Agriculture. Estonian Agriculture, 18. 
dependent upon the Soviet planned economy. This constitutes the basis for several problems that have appeared in the post-Soviet agricultural transformation process.

Since the late 1950s Estonia seems to have shown higher agricultural productivity than other Soviet republics which however cannot be fully confirmed by this study. But it is reasonable, as several scholars have done, to assume that the institutional preconditions, due to the interwar independence, played a major role for this performance. In spite of the nationalisation of land, the remaining farmsteads and the attached private plots offered at least an imaginary continuity, which was different from that of most other republics.

From the perspective of property right there were, after Khrushchev's reforms in the late 1950s, gradual changes in terms of internal and external control. In the Baltic republics the plotholders seem to have become gradually more independent. This increased when more investments were given to the large-scale farms, which had spin-offs on the private plots. The fact that many people did not see a clear-cut border between the kolkhoz farmland and the plot was probably important for agricultural production in general. After the abolishment of compulsory deliveries and the rise in procurement prices the incentives for small-scale producers further improved. The eternal problem, however, between equity and efficiency seems to have been better solved in Estonia due to a more efficient or successful agricultural administration based on native leadership. While the first kolkhoz members and sovkhoz workers in Estonia were more reluctant towards large-scale farming, the second and third generation apprehended this in a different way. The fact that there was a movement back into the countryside from the late 1970s on might also have implied that strict economic incentives, rather than perceptions of the interwar independence, ruled. Better housing conditions and better access to foodstuffs were probably as good as any other motive for people to move into the countryside.

However, in the 1980s, when all kinds of perceptions and experiences were mixed: old people told about the good old days and younger people saw that farm earnings from a few hectares were quite substantial, the myth of small-scale farming was nourished by the contemporary crisis in large-scale farming and the distorted price relations as well as the imaginary perceptions of the interwar past. By then the reorganisation of farm-work into family based units from the early 1980s had also proved to yield better in the socialised farming sector and therefore the family as a unit for production was considered more efficient.

Both during the Soviet period and since 1991, the production on private plots and subsistence holdings has been a response to struggles of a political or ideological character. The main difference, however, is constituted by the fact that the Soviet system throughout its existence developed into a direction in which small-scale farming became indispensable for most people. From an institutional point of view the private plots, which were supposed to be transitional solutions, could not be abandoned. It is possible to see a similar pattern in the post-Soviet period as well as after the dissolution of kolkhozes and sovkhozes. In the same way as the Soviet system contributed to insecurity in food supply, due to short- 
comings of the centralised planned economic production system, the period of market economic reforms after 1991 has not been able to provide social security and support. Many subsistence producers have lacked appropriate machinery and inputs, which has forced them into a dependency on cultivation resembling the production on private plots. More land and ownership rights have not contributed to any major differences in this regard.

The development of private plots in the Estonian Soviet republic from the late 1940s, and the subsequent development of subsistence holdings after 1991 can therefore be interpreted on the one hand as continuity from the perspectives of traditional family farming. Here the post-Soviet period has supplied an alternative to the large-scale production for which there has been a widespread aversion. In fact the Estonian peasantry has experienced very few and short periods of independent farming and statehood: the interwar period and 13 years after the regained independence, which probably has strengthened feelings for creating historical justice. In this regard the analogy between the masters on the BalticGerman estate and the Soviet kolkhoz chairmen can be understood. On the other hand, the subsistence holdings have, as successors to the private plots, been necessary for some of the least well off rural people. Thus both the private plots and the present subsistence holdings have functioned as a means for adjustment during times of hardships.

However, from the perspective of continuity a major change came in 2001. In contrast to the first 10 years of independence, when the regulations in farming were quite modest, the last years have meant a shift, both due to the impact of foreign competition and the adjustments to EU regulations. This has totally altered the preconditions for small-scale production and due to the profound economic and political transformation, it is reasonable to assume that the forthcoming ten to fifteen years will lead to even more radical changes in the Estonian farm structure. This will hardly imply a gradual change of the kind we have seen in Northern Europe since the 1950s. Within a few years we will most certainly see an expansion of Estonian farms to possessing 200-300 ha per unit, which will be highly competitive in the production of milk and meat.

If we return to the second interpretation, which relates to the subsistence function, this perspective also deserves a long-term analysis. In relation to the major farm units to which they were attached, private plots, subsistence holdings and even the pre-independence small piece of land belonging to the Baltic-German barons constituted the basis for the household's consumption. The lack of sufficient money incomes was overcome in a similar way during the Soviet period and in fact for many people even after 1991. What is remarkable is the fact that the private plots could never be abandoned in the socialist system and during the transformation process they actually proved to be even more important for many households.

In the economic sense, the private plots and subsistence holdings have provided both money incomes and foodstuffs for consumption: a kind of security, which the Soviet system and the post-Soviet transforming society were unable to deliver to sufficient degrees. Secondly, in an informal institutional sense, the private plots 
became an area in which small-scale farming and parts of the lost independence were preserved. Thereby the transfer into subsistence holdings, which might have had the ambition to become regular family farms, can be understood. Finally, and somewhat speculatively, the development of subsistence holdings could be seen as a deliberate political move. The fact that land was restituted and thereby brought forward obsolete property relations, i.e. average farm sizes resembling Estonia in 1939 , implied that an important symbolic question was solved. When this was matched with the application of the most liberal economic principles in trade and the minimal state, there were no needs for a coherent agricultural policy since small-scale producers were used to supply for themselves the basic foodstuffs.

As far as the property relations are concerned, the tremendous growth of smallscale farm holdings in re-independent Estonia after 1991 represents continuity with the interwar family farms. Restitution has re-created a farm structure that at least up to around 2001 was comparable to the interwar structure. While the interwar peasants obtained property rights in 1926, the same process was not fully concluded in Estonia by 2004 due to several related factors. One reason was the mix-up between Soviet law and Estonian law. In 1988-1991 the reform farmers obtained eternal leases to their land, which later was claimed by the legal owners that used restitution after 1991 as a means to get back their property.

This survival of small-scale farming is not solely explained by the fact that the official policies have been directed towards erasing Soviet legacies by means of restitution. The Soviet period also provided a shelter for small-scale farm activities in the form of private plots, which became both a substitute for the loss of private farming after nationalisation as well as a transmitter of the interwar family farming ideals. This is an obvious pattern of continuity. As it was explained by Abrahams, the experiences from the work on private plots helped "in an important way to keep people ready for the re-emergence of private farming and, as their hectarage increased during the late 1980 s, they diverted labour and commitment away from the collective sector". ${ }^{61}$

If we take this development into the context of the setbacks due to Soviet annexation in 1940, which was followed by land reform (maximum restrictions), increased taxes in 1947, deportations and forced collectivisation in $1948-1950,{ }^{62}$ the aversion to large-scale farming can be understood and merged with the perceptions of the 19th century.

It is also possible to see a gradual development of property rights due to the specific autonomous development under the reign of Khrushchev, which was followed by Brezhnev's justification of private plots. Against the decrees from Moscow, Estonia also withheld the size of private plots even when kolkhozes merged into sovkhozes. This in fact prepared for a development that deviated from the other Soviet policies on centralisation, specialisation and concentration that characterised the Brezhnev era. When private homes, instead of high apartment

\footnotetext{
61 Abrahams, R. (ed.). After Socialism, 13.
}

62 Kõll, A.-M. Tender wolves, 131. 
houses, were built in the countryside in the 1980s, this meant that more people would in the future have the oppotunity to have houses attached to agricultural land.

The continuity pattern here is therefore represented both by the survival of the family farm as a production unit, in spite of the Soviet system's aspiration on large-scale production, and by the gradual - but rather informal - adjustments in property rights that allowed for preservation of family farming ideals even within the planned economy. These ideals were preserved on the private plots for many years but transmitted into the pre-independence reform holdings that preceded restitution, and then maintained as subsistence holdings and small farms.

One palpable feature of present-day Estonia is the absence of a resurrected co-operative movement. The co-operative idea has been distorted by Soviet connotations, such as the co-operation within kolkhozes, which embedded few of the principles associated with the co-operative ideals. This can illustrate a specific transformation problem implying that the Soviet period's strong emphasis on collective principles instead led to strong feelings and perceptions of individualism, even before 1991, since the final years led to expanded production on private plots. In contrast, there was a profound growth of co-operative associations in the 1920 s, which also must be seen in relation to the economic integration needed in many new nations that had been parts of the dissolved empires. ${ }^{63}$

The adjustment to the demands from consumers in Europe needed a reorganisation of both agricultural production and its related up-stream and down-stream industries $^{64}$. Up to the worldwide economic crisis in the late 1920s Estonian producers succeeded through specialisation and commercialisation of export production, based on the strong triangular relationship between the Estonian agricultural co-operative associations, the government and the family farmers. ${ }^{65}$

In a long-term perspective, there was some continuity between the first independence and the Soviet period since both systems - though using totally different methods - supplied the farms, small-scale or large-scale, with an institutional structure for processing, refinement and services. In the 1920s and 1930s, the strong co-operative producers' associations and state support and credits were available. After the loss of both national independence and the independence for the co-operative associations, the Soviet structure supplied the kolkhozes and sovkhozes and even the private plots with similar services.

A major discontinuity in the post-Soviet development is therefore the loss of co-operative ideals, which partly can be explained by the fact that even though the Soviet system supplied inputs and services for the agricultural sector, the production on private plots went into a different individualistic direction. People

63 Kõll, A.-M. \& Valge, J. Economic nationalism and industrial growth. State and industry in Estonia 1919-39. - Studia Baltica Stockholmiensia, 1998, 13-14.

64 Upstream industries here refer to the manufacturers and suppliers of inputs, e.g. seed, fertilisers, machinery, etc. The downstream industries are e.g. dairies and slaughterhouses that process and market milk and meat products.

65 Jörgensen, H. Continuity or Not?, 96-97. 
became used to taking the car to the market and spending hours selling their produce. The family became a production unit, which used the common resources from the kolkhoz but chose to market on an individual basis, which generated more money than other types of work due to the distortion in pricing between input and output prices. From this perspective it can be explained why the resurrected farmers in the 1990s complained about the reduced returns. Cheap imported products were available, while fuel, fertilisers and seed had to be bought for hard currency. In this environment, subsistence producers grew rapidly in numbers. Land could not even be sold due to a lack of legal documents, and marketing was aggravated by low demand, cheap imports and double Russian tariffs on Estonian goods.

The pattern of continuity is here illustrated by the individualistic attitudes in production that were evidently present in the interwar period as well as after 1991. But in the 1920s and 1930s individualism was merged with the necessity to co-operate in refinement, purchases and sales, since the surrounding markets were impossible to conquer without the support of a strong organisation. The 1930s, however, slowly turned the co-operative organisations into the hands of the state, which was responsible for the bilateral agreements. A similar case was the Soviet period, which offered 'securer' markets. There were no alternatives to plan fulfilment, but this could also partly be managed through individual efforts on the private plots, which gave better return for the household, when the produce was sold on the kolkhoz markets. Thus peasants learned for many years that smallscale production was efficient, not least in the 1980s when the demand was huge and foreign competition was absent. What can be regarded as discontinuity is therefore probably the fact that peasants in the 1920s had to adjust because they were producing in a highly competitive environment. In the 1930s, markets were shrinking and they were forced to adjust to state control of export production, while the force used by the Soviet system from 1940 onward did not - in spite of collectivisation - contribute to a change of attitudes, such as support for co-operation in Soviet terms. Kolkhoz members and even sovkhoz workers rather chose to leave the co-operative idea, since the system supplied incentives for - although limited - individualism.

It is also striking that in some aspects the last ten years of the interwar period have more in common with the Soviet period than the post-Soviet development. This is obvious from the perspective of trade and state involvement in export, particularly agricultural export, not to mention the reach of the state in general. Even in international terms, due to trade regulations, this seems to represent more continuity. The international environment that appeared after 1989/91 thereby represents more of discontinuity due to the fall of the Berlin Wall and the dissolution of the Soviet Union and CMEA. Ironically, these new institutional preconditions came almost simultaneously with the deepening European integration, which again meant new institutional arrangements, not least as far as agricultural production and agricultural trade were concerned. 
The Estonian government realised in the early 1920s that an industrial recovery was impossible due to the break with Russia. But then the co-operative organised export production of meat and butter showed alternatives. The role of the state was crucial from the first day of independence and state involvement was nothing new. However, the first 12-14 years of independence was a rather short interlude when liberal economic principles seemed to fit.

Estonia's preconditions for trade became less favourable from the late 1920s due to the increased dependence on bilateral agreements and specific markets that developed. This led to centralisation and an increased role of the state in organising and controlling the export sector and by means of import substitution trying to overcome the loss of market shares. For the Estonian peasant producers, which had searched and strived for integration with the West, and to overcome a developmental gap after 1918, Estonia's relative position had been positive since the Baltic provinces were the most industrialised parts of the Tsarist Empire.

As in other parts of East and Western Europe, the depression created widespread discontent. The previous Tsarist system had been both centralised and led by a strong executive power and as early as in the late 1920s, when the first signs of the depression appeared, state involvement in the economy increased due to the many indebted co-operative and private enterprises and the aggravated conditions of trade. The Estonian state became a strong executive power in comparison with the many weak coalitions, which up to 1933 had left office, foremost due to internal struggles. One major outcome, besides the increased state involvement, was that the depression fostered new bilateral relations in trade. ${ }^{66}$

Under the period of authoritarian rule in 1934-1938 the economy was organised along corporative principles with profound state supervision in all sectors of production, not least the export sector. The productive forces were subjected to profound governmental control for the purpose of national welfare. ${ }^{67}$ Another example of this was the agriculturally dominated Bulgaria, which in the first years of the 1920s was the most obvious case where the corporatist ideology was put forward based on rural/agrarian values. ${ }^{68}$

Up to the depression, the conditions for trade were from the Estonian perspective relatively interdependent. However, state intervention and a turn towards dependence - through bilateral agreements in a time of shrinking markets - altered these conditions in the 1930s. The Soviet annexation in 1940 thereafter rapidly forced Estonia to become fully integrated with - and dependent on - the Soviet market, which after 1945 expanded further in East-Central Europe. Estonia was thus subjugated to the all-Union division of labour and the forced collectivisation in the late 1940s totally transformed the agricultural production system and its related activities. From the mid 1950s on, the expansion of agricultural production and

66 Jörgensen, H. Continuity or Not?, 107-109.

67 Kõll, A.-M. \& Valge, J. Economic nationalism and industrial growth, 56-58.

68 Bell, D. Peasants in Power. Alexander Stamboliiski and the Bulgarian Agrarian National Union, 1899-1923. Princeton, 1977, 59-61. 
markets was therefore totally led by, and dependent on, Soviet demands through the CMEA. With the altered opportunities that came after the end of the Cold War and the fall of the Soviet Union, the step-wise integration of former planned economies in WTO and, not least, the enlargement process of the European Union, a different kind of dependence has appeared. This can be seen from the perspective of altered rules of the game.

With the introduction of a planned economy in the 1940s and the reorientation of trade towards the Soviet Union, Estonia had therefore already experienced stateled export orientation and dependence on few markets. The lack of multilateral agreements in the 1930s and the neo-mercantilist tendencies visible in e.g. export bonus payments, pointed to autarchic solutions. The Soviet system of trade and production within the CMEA sphere was in fact very much directed towards similar principles of economic nationalism and a wish to become independent of the existing world market by pooling the productive resources within the CMEA.

In the early 1990s, however, the European markets were not as open as in the early 1920s. Furthermore, the short-term period available for adjustment among the former planned economies since 1991 can be compared to the corresponding development in Western Europe after 1950. The EU member states have used various protective means for the development of their welfare states and not least, different protective measures for their agricultural sectors. The harsh and relatively successful macroeconomic adaptation, which Estonia has carried out since independence, has however not resulted in equal performances in all sectors of the economy. The agricultural development is therefore to a large extent dependent upon the future market conditions and quotas within the EU. From the Estonian point of view, the weakened role of the state since the late 1980s and the corresponding increased dependence on the international environment, especially the EU, constitutes an important change. Especially after independence in 1991 this pattern is deviating from the first ten years of interwar independence. While the Estonian state has step-wise diminished its influence in agricultural issues the impact of the EU has expanded.

The development since 1987 is illustrative. Through independence and currency reform the whole market situation was changed since the previously cheap Russian farm inputs were to be paid for in hard currency. Total agricultural production therefore underwent a steep decline of around 50 per cent between 1989 and 1994. After 1995, the export of Estonian foodstuffs to Russia actually recovered temporarily, despite the fact that in 1994 Russia had imposed a specific tariff on Estonian goods ${ }^{69}$ In 1997, entrepreneurs therefore saw excellent prospects for reclaiming the former markets, which in fact had been an initial hope in the early 1920s as well. The general decrease in demand, declining imports of inputs and the Russian financial crisis brought down the share of agricultural products in total Estonian export from 17.5 to 5.8 per cent between 1992 and $2000 .^{70}$

69 Review of Agricultural Policies, 53.

70 Ministry of Agriculture. Estonian Agriculture, 8. 
In comparison to the interwar period when the state was active in agricultural issues and supported the expansion in refinement industries and export, which to some extent continued during the Soviet years as well, the post-Soviet development forms a major discontinuity. First, due to the different role of agricultural production, the loss of the Russian markets has meant roughly a 50 per cent reduction of agricultural production. Secondly, because the first ten years after independence were characterised by several parallel processes, such as reconstruction of agricultural production, property relations, and the simultaneous exposure to foreign competition, while at the same time Estonia did not have access to the European markets. This pattern has no previous analogue. However, the Estonian membership in the European Union from May 2004, and thereby full access to EU funding, might well imply that after more than 60 years, Estonian butter and meat will start to retake the markets they lost in 1939. Thus, even if Estonia probably maintains a smaller agricultural sector than during the Soviet period, the competitive forces will be there. The youngest of my informers told me that he had no illusions about being supported by the government in the future. He said, and his mother agreed, "The hard liberalisation created severe elimination in the last ten to twelve years, but now I am prepared and can see some better days ahead." ${ }^{, 71}$ Within the forthcoming EU membership in mind he did not have any doubts about the fact that he would be one of the successful in the future.

71 Interview with C. R. (farmer in Tartumaa), February 2004.

\section{ELATIST ANDEV TALUPIDAMINE TAASISESEISVUNUD EESTIS: LAIENENUD MAAVALDUSED}

\section{Hans JÖRGENSEN}

Eestis on kogu 20. sajandi jooksul olnud tähtis osa taludele rajatud tootmisel, vaatamata sellele et Eesti annekteerimine ja sundkollektiviseerimine tegi 1940. aastail eraomandusele lõpu. Nõukogude süsteemi areng toimus selles suunas, et väikemaa harimine muutus hädavajalikuks enamikule inimestest. Nõukogude süsteem ei taganud piisavalt toiduainetega varustamist seoses tsentraliseeritud plaanimajanduse puudustega ja seetõttu omandas isiklik maalapp äraelamisel järjest suurema tähtsuse. Ka 1991. aastal taasiseseisvunud Eestis käivitunud restitutsioon ja reformid, mille eesmärk oli üleminek turumajandusele, ei pakkunud esialgu majanduslikku tuge ega sotsiaalset turvalisust. Eesti taasiseseisvumise kümne esimese aasta jooksul oli valitsusepoolne põllumajanduse regulatsioon tagasihoidlik. Pööre tuli 2001. aastal seoses välismaise konkurentsi mõju suurenemisega ja Euroopa Liidu põllumajandusalaste regulatsioonide (normide ja standardite) omaksvõtmisega. See muudab oluliselt majanduskeskkonda ja ahendab väiketalude ellujäämise võimalusi. Seetõttu on põhjust oletada, et järgmise 10-15 aasta jooksul muutub Eesti põllumajanduse struktuur radikaalselt suurfarmide kasuks. 